\title{
Role of Interferon-gamma and Interleukin-12 in the Immunopathogenesis of Hepatitis B Virus Infection
}

\author{
Meher Rizvi, Mohd Azam, MR Ajmal, Abida Malik, Indu Shukla, Nishat Afroz
}

\begin{abstract}
Objective: To study the role of interleukin (IL)-12 and interferon (IFN)- $\gamma$ in immunopathogenesis of hepatitis B virus (HBV) infection.
\end{abstract}

Materials and methods: One hundred and fifty-seven patients with hepatitis $B$ were screened by serological and molecular markers for HBV. Serum IL-12 and IFN- $\gamma$ levels were estimated.

Results: Among patients with acute HBV (AHB), the mean levels of IFN- $\gamma(52.35 \mathrm{pg} / \mathrm{ml})$ and IL-12 $(57.12 \mathrm{pg} / \mathrm{ml})$ were significantly higher in patients with nonnecrotizing inflammation (NNI) compared to those in patients with necrotizing inflammation (NI) $(32.17 \mathrm{pg} / \mathrm{ml}$ and $42 \mathrm{pg} / \mathrm{ml}$ for IFN- $\gamma$ and IL12 respectively). In chronic $\mathrm{HBV}(\mathrm{CHB})$ with $\mathrm{NI}$, IFN- $\gamma$ levels were much higher than the same in AHB. However, no significant difference was found in IL-12 levels. IL-12 levels $(25.76 \mathrm{pg} / \mathrm{ml})$ were lower in NNI of CHB patients, while the levels of IL-12 were comparable between NI patients with $\mathrm{AHB}$ and $\mathrm{CHB}$. Both IFN- $\gamma$ and IL-12 were higher in hepatitis $\mathrm{B}$ e-antigen (HBeAg)-negative patients than $\mathrm{HBeAg}$-positive patients. .

Conclusion: Both IFN- $\gamma$ and IL-12 appear to play a role in AHB and $\mathrm{HBeAg}$ negativity, however, further study will be required to get their precise role.

Abbreviations: AHB: Acute hepatitis B virus; $\mathrm{CHB}$ : Chronic hepatitis B; NI: Necrotizing inflammation; NNI: Nonnecrotizing inflammation; IFN: Interferon; IL: Interleukin; AHB: Acute hepatitis B; CHB: Chronic hepatitis B; HBeAg: Hepatitis B e-antigen; MELD: Model for end-stage liver disease; CTL: Cytotoxic T cells.

Keywords: Acute hepatitis B, Chronic hepatitis B, Interferongamma, Interleukin-12, Necrotizing inflammation, Nonnecrotizing inflammation.

How to cite this article: Rizvi M, Azam M, Ajmal MR, Malik A, Shukla I, Afroz N. Role of Interferon-gamma and Interleukin-12 in the Immunopathogenesis of Hepatitis B Virus Infection. Euroasian J Hepato-Gastroenterol 2012;2(1):5-9.

\section{Source of support: Nil}

\section{Conflict of interest: None}

\section{INTRODUCTION}

The hepatitis B virus (HBV) is a noncytopathic DNA virus that causes acute and chronic hepatitis and hepatocellular carcinoma. ${ }^{1}$ Patients who successfully clear acute HBV infection characteristically mount a strong, polyclonal and multispecific cytotoxic T lymphocyte (CTL) response to $\mathrm{HBV}^{2-6}$ that lasts for decades following recovery, which is probably maintained by traces of virus that persist indefinitely after clinical and serological recovery. Approximately $5 \%$ of adults and $95 \%$ of neonates who become infected by HBV develop persistent $\mathrm{HBV}$ infection ${ }^{7}$ which now affects more than 300 million people worldwide. ${ }^{8}$ The immune determinants of successful clearance of HBV are not fully understood but both cellular and humoral immune responses are important. ${ }^{6,9,10}$ At the same time, liver inflammation and disease are also believed to be largely immune-mediated. Therefore a complex interaction exists between HBV and the host in initial clearance of HBV, the long-term persistence of $\mathrm{HBV}$ and the pathogenesis of $\mathrm{HBV}$ related liver diseases. Recent studies have defined two $\mathrm{T}$ helper cell subsets, ${ }^{11-13}$ Th1 and Th2, which are characterized by distinct and mutually exclusive patterns of cytokine production and different functions. ${ }^{14}$ Th1 cells produce interferon (IFN)- $\gamma$ and interleukin (IL)-12 and promote cellular immune reactions while $\mathrm{Th} 2$ cells produce IL-4, IL-5, IL-10 and enhance humoral immune response. Th1/Th2 imbalances are important in the pathogenesis of chronic viral infections in humans. ${ }^{15}$

The aim of our study was to investigate the immunoregulatory role of IL-12 and IFN- $\gamma$ in various serological stages of acute hepatitis B (AHB) and chronic hepatitis B (CHB) infections.

\section{MATERIALS AND METHODS}

Five hundred and sixty-five consecutive patients with hepatitis attending the hepatitis clinic or admitted in the Medicine wards of Jawaharlal Nehru Medical College, Aligarh Muslim University, Aligarh, India were screened for viral hepatitis. This study was conducted over a one and half years from August 2008 to January 2010 in the Department of Microbiology. All patients underwent complete physical examination and detailed clinical history was obtained from them. The study was approved by the institutional ethical committee of Jawaharlal Nehru Medical College, Aligarh Muslim University, India. A written informed consent was obtained from each patient.

\section{Exclusion Criteria}

Patients with autoimmune hepatitis, alcoholic hepatitis, drugs-induced hepatitis, patients giving history of recent infection, surgery, trauma within the preceding 2 months, renal insufficiency or with other acute or chronic inflammatory diseases were excluded from this study. None of the participants had received any antiviral or 
immunosuppressive therapy before or during the course of this study.

\section{Necrotizing and Nonnecrotizing Inflammation}

Necrotizing and nonnecrotizing inflammation were defined on the basis of biochemical and histopathological parameters. In necrotizing inflammation (NI) the liver function tests were considerably deranged and there was extensive damage to liver parenchyma. In AHB-NI significant necrosis (bridging necrosis and/or interface hepatitis) were seen while in CHB-NI infection moderate/ severe portal inflammation, moderate/severe interface hepatitis and focal/considerable lobular inflammation were observed. In nonnecrotizing inflammation, the liver function test were either normal or mildly elevated and there was minimal to mild histopathological changes. In AHB-NI, insignificant necrosis (isolated dropout necrosis of hepatocytes) and in CHB-NNI mild portal inflammation, mild interface hepatitis and few foci of lobular inflammation were observed.

\section{Clinical Grading}

Clinical grading was done on the basis of biochemical investigations and clinical status of patient into mild moderate, severe and end stage liver disease using the model for end-stage liver disease (MELD) score.

\section{Healthy Control Individuals}

The control group consisted of 30 healthy people of comparable age; male; 22 and female; 8 with a mean age of 37 years. These individuals were negative for $\mathrm{HBsAg}$ as well as for anti-HCV and anti-HIV antibodies.

\section{Collection of Specimen}

For all serological assays, venous blood samples were obtained from a peripheral vein with informed consent of all subjects. After centrifugation the serum was stored at $-40^{\circ} \mathrm{C}$ until used for study.

\section{Routine Investigations}

Liver function tests (LFT) like serum amino alanine transaminase (ALT), serum aspartate amino transferase (AST) and alkaline phosphatase (ALP), bilirubin (direct and indirect ) total bilirubin, albumin, globulin, creatinine and international normalized ratio for prothrombin time were performed. Specific investigations like ultrasonographic examination of liver, upper GI endoscopy and liver biopsy were performed wherever feasible.

\section{Primary Screening}

All patients with hepatitis were screened for HAV, HBV, $\mathrm{HCV}, \mathrm{HEV}$ and HIV by commercially available ELISA kits according to the manufacturer's instruction using the following kits: $\mathrm{HBsAg}$, third generation anti-HCV, fourth generation anti-HIV (J. Mitra \& Co. Pvt. Ltd., New Delhi, India), anti-HAV IgM and anti HEV IgM (DRG International, Inc., East Mountainside, NJ, USA). Patients positive for HBV were enrolled for further study. All cases of acute $\mathrm{HBV}$ infection were followed up for 6 months to assess seroconversion to anti-HBS (DRG International, Inc.). All cases which seroconverted to anti-HBS were included in acute HBV group. One hundred and fifty-seven patients with acute and chronic hepatitis B were subjected to secondary screening.

\section{Secondary Screening}

Serological status of $157 \mathrm{HBV}$ positive patients (34 acute and 123 chronic HBV cases) were determined using the following kits: HBeAg, anti-HBe, anti-HBc IgM (DRG International, Inc.) and anti-HBc Plus (Monolisa ${ }^{\mathrm{TM}}$, BioRad, Marnes-la-Coquette, France). HBV DNA was assessed in all patients with hepatitis by polymerase chain reaction.

\section{IL-12 and IFN- $\gamma$ Assay}

To measure IL-12 and IFN- $\gamma$ levels in serum of HBV infected patients and in healthy controls, ELISA kits were procured from Orgenium, Helsinki, Finland and Diaclone, Besancon Cedex, France respectively. The ELISA kit protocols were followed as per the manufacturer's instructions. The detection limit of the IL-12 assay was $2 \mathrm{pg} / \mathrm{ml}$ and IFN- $\gamma$ was $5 \mathrm{pg} / \mathrm{ml}$.

\section{Statistical Analysis}

Correlations between continuous variables were assessed by the Spearman rank test, corrected for ties, where a value of $p>0.25$ (combined with $p<0.05$ ) was considered significant. The nonparametric Mann-Whitney U- test was used to determine the significance of differences in continuous variables. The level of significance in all cases was set at a two tailed $\mathrm{p}<0.05$.

\section{RESULTS}

\section{Clinical Profile}

The clinical profile of patients with acute and chronic HBV infection is given in Table 1. Majority of patients with acute AHB presented with nausea, fever, jaundice, vomiting, anorexia and hepatomegaly. Common complaints of patients with $\mathrm{CHB}$ were anorexia, jaundice, nausea, splenomegaly 


\begin{tabular}{|c|c|c|}
\hline & Acute HBV patients $(n=34)$ & Chronic HBV patients $(n=123)$ \\
\hline Fever & 27 & 51 \\
\hline Anorexia & 19 & 117 \\
\hline Nausea & 29 & 108 \\
\hline Vomiting & 21 & 65 \\
\hline Jaundice & 25 & 113 \\
\hline Fatigue & 26 & 101 \\
\hline Hepatomegaly & 16 & 91 \\
\hline Splenomegaly & - & 103 \\
\hline SGOT* $^{*}$ & $160.33 \pm 293.37$ IU/I & $29.1 \pm 19.27 \mathrm{IU} / \mathrm{I}$ \\
\hline SGPT* & $127.16 \pm 170.68 \mathrm{IU} / \mathrm{I}$ & $29.1 \pm 17.02 \mathrm{IU} / \mathrm{I}$ \\
\hline $\mathrm{ALP}^{*}$ & $19.91 \pm 5.89 \mathrm{kau} / 100 \mathrm{ml}$ & $10.9 \pm 6.39 \mathrm{kau} / 100 \mathrm{ml}$ \\
\hline Serum bilirubin* & $13.66 \pm 12.95 \mathrm{mg} / 100 \mathrm{ml}$ & $2.75 \pm 4.40 \mathrm{mg} / 100 \mathrm{ml}$ \\
\hline Ascites & - & 18 \\
\hline Weight loss & - & 37 \\
\hline Necrotizing inflammation & 21 & 88 \\
\hline Nonnecrotizing inflammation & 13 & 38 \\
\hline HBV DNA & 29 & 111 \\
\hline
\end{tabular}

${ }^{*}$ Data are shown as mean \pm SD values

and hepatomegaly. Of 34 AHB patients, 21 (63.63\%) cases had necrotizing inflammation (NI) and 13 (36.37\%) had nonnecrotizing inflammation (NNI). According to MELD scoring, 28 (84.84\%) had mild, two (6.06\%) moderate and three $(9.09 \%)$ had severe end-stage liver disease (ESLD). Out of 123 CHB patients with CHB, 87 (70.73\%) had NI and $36(29.27 \%)$ had NNI. Forty-seven (38.21\%) had mild, $46(37.39 \%)$ moderate and $30(24.39 \%)$ had severe liver disease; 11 had ESLD. HBV DNA was detected in 29 cases (87.87\%) of AHB and in 111 (90.2\%) cases of CHB.

\section{Laboratory Profiles}

All the parameters of liver damage were significantly higher in patients with AHB than CHB $(\mathrm{p}<0.001)$ (Table 1). While HBsAg was positive in all cases, 25 (73.5\%) cases in AHB and 59 (47.96\%) cases in CHB group were positive for $\mathrm{HBeAg}$. All cases of AHB were anti-HBc IgM positive while all cases of $\mathrm{CHB}$ were anti$\mathrm{HBc}$ IgG positive.

\section{Serum Cytokine Levels}

The levels of IFN- $\gamma$ and IL-12 in controls and patients have been summarized in Figures 1 and 2 respectively. As shown in Figure 1, the levels of IFN- $\gamma$ were significantly elevated in patients of AHB and CHB compared to controls $(\mathrm{p}<0.05)$. In the healthy controls, mean level of IFN- $\gamma 11.33 \mathrm{pg} / \mathrm{ml}$, while it was $42.26 \mathrm{pg} / \mathrm{ml}$ in AHB and $66.95 \mathrm{pg} / \mathrm{ml}$ in CHB. The levels of IFN- $\gamma$ were also higher in NNI than in NI in both AHB and CHB (Fig. 1).

In healthy controls, the mean level of IL-12 was 39.14 $\mathrm{pg} / \mathrm{ml}$. In patients with AHB and CHB, these were 49.56 and $34.88 \mathrm{pg} / \mathrm{ml}$ respectively (Fig. 2).

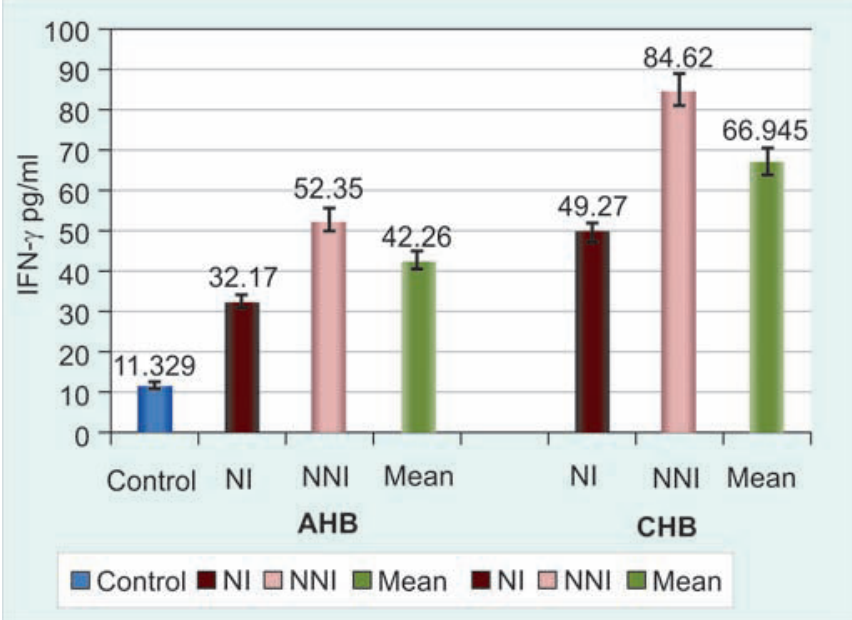

Fig. 1: Serum levels of interferon (IFN)- $\gamma$ in healthy controls and in patients necrotizing inflammation ( $\mathrm{NI}$ ) and nonnecrotizing inflammation (NNI). AHB: Acute hepatitis B; CHB: Chronic hepatitis B

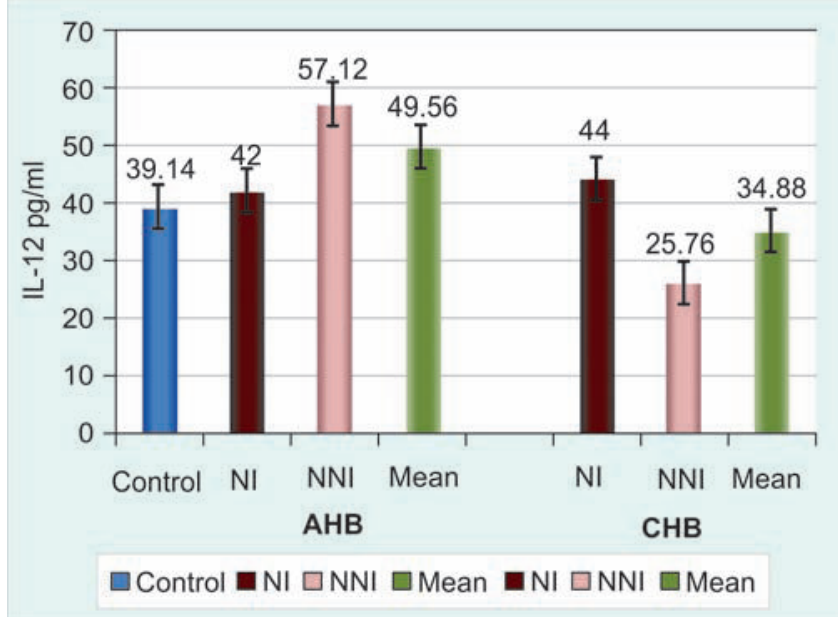

Fig. 2: Serum levels of interleukin (IL)-12 in healthy controls and in patients necrotizing inflammation (NI) and nonnecrotizing inflammation (NNI). AHB: Acute hepatitis B; CHB: Chronic hepatitis B 


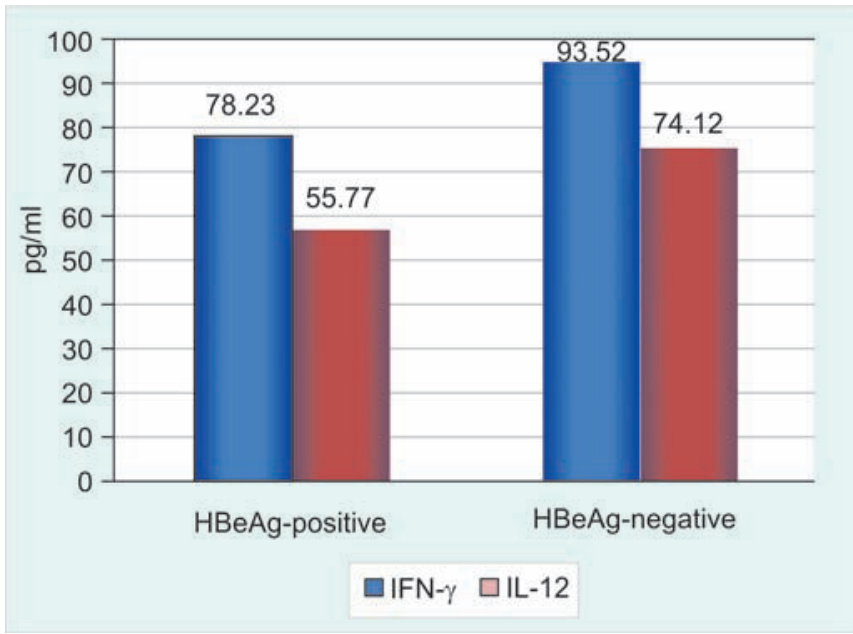

Fig. 3: Serum levels of IFN- $\gamma$ and IL-12 in the HBeAg-positive and $\mathrm{HBeAg}$-negative patients

The levels of both IFN- $\gamma$ and IL-12 were higher in HBeAg-negative patients compared to HBeAg-positive patients with CHB (Fig. 3).

\section{Association of Cytokines with Clinical Status of Patients}

The patients were divided into three clinical groups: Mild, moderate and severe liver disease. Comparatively higher levels of IFN- $\gamma$ levels were observed in majority of patients with mild hepatitis. Lowest levels of IFN- $\gamma$ were predominantly seen in the ESLD patients. IFN- $\gamma$ levels were higher in clinically stable patients than in the unstable patients (mean levels; $93.86 \mathrm{pg} / \mathrm{ml}$ vs $39.17 \mathrm{pg} / \mathrm{ml}$ respectively $)(\mathrm{p}<0.001)$.

\section{DISCUSSION}

In this study, we analyzed the serum concentrations of IFN- $\gamma$ and IL-12 in relation to AHB and CHB. We also assessed the cytokine levels in relation to NI and NNI, and HBeAg status in serum and the clinical conditions of the patients. Levels of IFN- $\gamma$ were significantly higher in patients with acute and CHB compared to healthy controls. IFN- $\gamma$ levels were higher in patients of CHB than in patients with AHB. Decreased levels of IFN- $\gamma$ in CHB cases have also been reported. Recent studies have reported either very low levels in different clinical groups or elevated levels in those with chronic HBV. ${ }^{17-20}$ Our observations are in agreement with other studies showing that serum IFN- $\gamma$ levels are elevated in HBV patients with different clinical presentations. ${ }^{19,20}$

IL-12 appears to play a preeminent role in prognosis of the disease, elevated IL-12 was associated with clinical progression and low levels were linked to worsening of the condition. The levels of IL-12 were higher in AHB than in
CHB. This suggests that IL-12 plays a more active role in containment of HBV infection.

Most studies have reported raised IL-12 levels ${ }^{16,20,25}$ in hepatitis. IL-12 has a central role in mounting an effective cellular immune response directed toward the elimination of intracellular pathogens and it is known that the production of this cytokine is important for viral clearance. ${ }^{15,16}$ The relative decrease of IL-12 production in CHB as seen in this study may be due to: (a) Low $\mathrm{T}$ cell stimulation of dendritic cells from HBV infected patients, ${ }^{21}$ (b) HBV infection itself and some cytokines induced by HBV infection may produce direct or indirect influences on transcriptions of IL-12 gene, ${ }^{22,23}$ (c) High level type 1 interferon in patients with HBV infection which induces down regulation of IL-12 secretions. ${ }^{24}$ The lower levels of IL-12 in CHB could be one reason for the chronicity of the disease. Our study suggests that effective immune therapy for chronic hepatitis should include both IL-12 and IFN- $\gamma$. Rossol ${ }^{16}$ has reported that successful IFN- $\gamma$ therapy for chronic HBV infection is specifically associated with elevated serum IL-12 p70 profile which in turn implies that defective or suppressed IL-12 $\mathrm{p} 70$ production leads to viral persistence. In a recent study investigating the immunoregulatory role of IL-12 and IFN- $\gamma$ in CHB children being treated with interferon alpha, it was found that responders had marked elevation of IL-12 while nonresponders continued having low levels of IL-12. ${ }^{26}$ IFN- $\gamma$ levels were higher in NNI cases in patients with either AHB or CHB suggesting its greater role in controlling HBV infection by noncytolytic mechanism. The highest levels of IL-12 were observed in NNI cases of AHB, which suggests IL-12 plays a dominant role in this condition. NNI cases had lower or normal levels of liver enzymes and patients were relatively stable. Thus, higher levels of IFN- $\gamma$ and IL-12 appear to tilt the clinical spectrum toward improved profile of liver markers and better clinical status. In CHB, although IFN- $\gamma$ was elevated in NNI, IL-12 was significantly lower which could be the reason for elevated liver enzymes, persistence of virus and poor clinical status.

Measurements of intrahepatic cytokines and cell mediated immune responses might provide a more meaningful picture. The invasive procedures required make this an impractical proposition in the human context but the rise of murine models has given considerable insight into the role of intrahepatic cytotoxic T-cells and cytokines (Chirasi 2000). Despite these disadvantages, we conclude that analysis of cytokine levels in well defined clinical and histopathological groups as described in this study can aid in clarifying our understanding of immunological events. This may lead to improvements of clinical management of patients with CHB. 


\section{ACKNOWLEDGMENT}

This work was supported by grants from Department of Science and Technology (DST), Ministry of Science and Technology, India.

\section{REFERENCES}

1. Tiollais P, Pourcel C, Dejean A. The hepatitis B virus. Nature (Lond.) 1985;317:489-95.

2. Penna A, Chisari FV, Bertoletti A, et al. Cytotoxic T lymphocytes recognize an HLA-A2-restricted epitope within the hepatitis B virus nucleocapsid antigen. J Exp Med 1991;174:1565-70.

3. Missale G, Redeker A, Person J, et al. HLA-A31- and HLAAw68-restricted cytotoxic $T$ cell responses to a single hepatitis $B$ virus nucleocapsid epitope during acute viral hepatitis. J Exp Med 1993;177:751-62.

4. Bertoletti A, Ferrari C, Fiaccadori F, et al. HLA class I-restricted human cytotoxic $\mathrm{T}$ cells recognize endogenously synthesized hepatitis B virus nucleocapsid antigen. Proc Natl Acad Sci USA 1991;1(88):10445-49.

5. Nayersina R, Fowler P, Guilhot S, et al. HLA A2 restricted cytotoxic $\mathrm{T}$ lymphocyte responses to multiple hepatitis $\mathrm{B}$ surface antigen epitopes during hepatitis B virus infection. J Immunol 1993; 150:4659-71.

6. Rehermann B, Fowler P, Sidney J, et al. The cytotoxic T lymphocyte response to multiple hepatitis B virus polymerase epitopes during and after acute viral hepatitis. J Exp Med 1995; 181:1047-58.

7. Chisari FV, Ferrari C. Hepatitis B virus immunopathogenesis. Annu Rev Immunol 1995;13:29-60.

8. Takano S, Yokosuka O, Imazeki F, Tagawa M, Omata M. Incidence of hepatocellular carcinoma in chronic hepatitis B and C: A prospective study of 251 patients. Hepatology 1995; 21:650-55.

9. Penna A, Del Prete G, Cavalli A, et al. Predominant T-helper 1 cytokine profile of hepatitis B virus nucleocapsid-specific T cells in acute self-limited hepatitis B. Hepatology 1997;25:1022-27.

10. Webster GJ, Reignat S, Maini MK, et al. Incubation phase of acute hepatitis B in man: Dynamic of cellular immune mechanisms. Hepatology 2000;32:1117-24.

11. Marinos G, Torre F, Chokshi S, et al. Induction of T-helper cell response to hepatitis $\mathrm{B}$ core antigen in chronic hepatitis $\mathrm{B}$ : A major factor in activation of the host immune response to the hepatitis B virus. Hepatology 1995;22:1040-49.

12. Tsai SL, Chen PJ, Lai MY, et al. Acute exacerbations of chronic type $\mathrm{B}$ hepatitis are accompanied by increased $\mathrm{T}$ cell responses to hepatitis B core and e antigens. Implications for hepatitis B e antigen seroconversion. J Clin Invest 1992;89:87-96.

13. Lohr HF, Weber W, Schlaak J, Goergen B, Meyer zumBüschenfelde KH, Gerken G. Proliferative response of CD41 $\mathrm{T}$ cells and hepatitis $\mathrm{B}$ virus clearance in chronic hepatitis with or without hepatitis B e-minus hepatitis B virus mutants. Hepatology 1995;22:61-68.

14. Paul WE, Seder RA. Lymphocyte responses and cytokines. Cell 1994;76:241-51.

15. Trinchieri G. Interleukin-12: A proinflammatory cytokine with immunoregulatory functions that bridge innate resistance and antigen-specific adaptive immunity. Annu Rev Immunol 1995; 13:251-76.

16. Rakela J, Ishizawa L. Failure to detect circulating interferon during acute viral hepatitis. J Infect Dis 1984;149:831.

17. Pirovino M, Aguet M, Huber M, Altorfer J, Schmid M. Absence of detectable serum interferon in acute and chronic viral hepatitis. Hepatology 1986;6:645-47.
18. Chu CM, Sheen IS, Yeh CT, Hsieh SY, Tsai SL, Liaw YF. Serum levels of interferon-alpha and -gamma in acute and chronic hepatitis B virus infection. Dig Dis Sci 1995;40:2107-12.

19. Song LH, Binh VQ, Duy, DN, et al. Serum cytokine profiles associated with clinical presentation in Vietnamese infected with hepatitis B virus. J Clin Virol 2003;28:93-103.

20. Rossol S, Marinos G, Carucci P, Singer MV, Williams R, Naoumov NV. Interleukin-12 induction of Th1 cytokines is important for viral clearance in chronic hepatitis B. J Clin Invest 1997;99:3025-33.

21. Orange JS, Wolf SF, Biron CA. Effects of IL-12 on the response and susceptibility to experimental viral infections. J Immunol 1994;152:1253-64.

22. Heufler C, Koch F, Stanzl U, et al. Interleukin-12 is produced by dendritic cells and mediates T helper 1 development as well as interferon- $\gamma$ production by T helper 1 cells. Eur J Immunol 1996; 26: 659-62.

23. Chouaib S, Chehimi J, Bani L, et al. Interleukin-12 induces the differentiation of major histocompatibility complex class Iprimed cytotoxic T-lymphocyte precursors into allospecific cytotoxic effectors. Proc Natl Acad Sci USA 1994;91:12659.

24. Thio CL, Thomas DL, Carrington M. Chronic viral hepatitis and the human genome. Hepatology 2000;31:819-27.

25. McRae BL, Semnani RT, Hayes MP, Seventer AV. Type 1 IFNs inhibit human dendritic cell IL-12 production and Th1 cell development. J Immunol 1998;160:4298-302.

26. Ozkan TB, Budak F, Erdemir G, Ozgur T, Aker S. Do Liver IL12 levels predict sustained response to IFN-alpha therapy in children with chronic hepatitis B? J Interferon Cytokine Res 2010;30:433-38.

\section{ABOUT THE AUTHORS}

\section{Meher Rizvi (Corresponding Author)}

Assistant Professor, Department of Microbiology, Jawaharlal Nehru Medical College, Aligarh Muslim University, Aligarh-202002 Uttar Pradesh, India, Phone: +91-9451403111, Fax: +91-571-2704498 e-mail: rizvimeher@yahoo.co.in

\section{Mohd Azam}

Department of Microbiology, Jawaharlal Nehru Medical College Aligarh Muslim University, Aligarh, Uttar Pradesh, India

\section{MR Ajmal}

Department of Medicine, Jawaharlal Nehru Medical College, Aligarh Muslim University, Aligarh, Uttar Pradesh, India

\section{Abida Malik}

Department of Microbiology, Jawaharlal Nehru Medical College Aligarh Muslim University, Aligarh, Uttar Pradesh, India

\section{Indu Shukla}

Department of Microbiology, Jawaharlal Nehru Medical College Aligarh Muslim University, Aligarh, Uttar Pradesh, India

\section{Nishat Afroz}

Department of Pathology, Jawaharlal Nehru Medical College, Aligarh Muslim University, Aligarh, Uttar Pradesh, India 